\title{
Paideusis
}

\section{On the Liberty and Logic of McMurtry}

\section{Richard Barrett}

Volume 7, Number 2, 1994

URI: https://id.erudit.org/iderudit/1073280ar

DOI: https://doi.org/10.7202/1073280ar

See table of contents

Publisher(s)

Canadian Philosophy of Education Society

ISSN

0838-4517 (print)

1916-0348 (digital)

Explore this journal

Cite this article

Barrett, R. (1994). On the Liberty and Logic of McMurtry. Paideusis, 7(2), 25-27.

https://doi.org/10.7202/1073280ar

(C) Richard Barrett, 1994

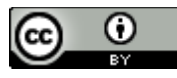

This document is protected by copyright law. Use of the services of Erudit (including reproduction) is subject to its terms and conditions, which can be viewed online.

https://apropos.erudit.org/en/users/policy-on-use/
This article is disseminated and preserved by Érudit.

Érudit is a non-profit inter-university consortium of the Université de Montréal, Université Laval, and the Université du Québec à Montréal. Its mission is to promote and disseminate research.

https://www.erudit.org/en/ 


\title{
On The Liberty and Logic of McMurtry
}

\author{
Richard Barrett, Elmira College, New York
}

The accusations made against my views by McMurtry in a recent issue of Paideusis $^{1}$ are severe and, at times, exotic. They include the charge of abandoning reason, assuming that the market necessarily enhances freedom, blocking out his argument that the market reduces freedom, and confusing the market model with alternatives in education.

I do not have the space to counter all of the accusations, which in any case, I believe, include mutually exclusive charges. I will, however, respond to some which most clearly indicate, or conceal, philosophical differences between us.

When I commented on McMurtry's paper, 2 I assumed that the quotation from a British politician-on a new paradigm responsive to clients-put at the head of it was germane to his argument. I also assumed that the whole opening section, dealing with things such as the loss of academic positions, was pertinent to his argument, and not just a ploy to secure from educators worried about such developments a ready acceptance of his so-called contradictions.

I am now not sure that these assumptions were true. In my comments, I referred to things such as alternatives and choices, flexibility, and job losses in Britain because they are among the many issues and changes that are the context from which the quotation was drawn. In as much as my comments were explicitly tied to it-as they were several times over, I maintain that I made no mistake at all.

Yet, McMurtry accuses me of major and multiple misunderstandings. There is, however, much that is strange about the delivery of these charges. For one thing, he does not actually accuse me of misunderstanding the quotation. What he says, instead, is that I assume from the start that the market model's application to education will expand the available choices, and:

This is an apparent necessary truth for him which is nowhere diverted by my continuous argument against it. It is simply assumed as a given through his reply-"expanded choice," "endless possibilities of interest and challenge," "people choose where and how to study," "increase in choice," "permitting a variety," "students will actually get to make a choice," "resulting greater choice," and so on. ... Barrett's assumption that the market model's application to education necessarily means ever more freedom is the one unifying idea of his reply. ${ }^{3}$

Most of the items that have been gathered here, in an obviously calculated manoeuvre, were tied to the quotation in my piece. It is only when detached from it that they can be offered as having McMurtry's own contrived "unifying theme." The quotation itself was, of course, their unifying theme.

Further, the items gathered include not a single use of the word "freedom," nor any cognate or synonym. Yet after this, McMurtry redoubles his accusation by claiming that I believe that "the market is freedom." In fact, my remarks about choices included reference to benefits other than freedom-such as the claim that, since serious choices require access to good information, a reduction in unhelpful documentation might ensue. John Stuart Mill, I believe, thought that an agent's choices are not free unless there is access 
to reliable information about the options. But McMurtry does not allude to my points about documentation when imputing to me a view about freedom. In any case, my view is that the difference between well-informed and uninformed choices is morally important irrespective of whether freedom is at stake. McMurtry's imputation that I think choices bring freedom is sheer invention.

Any potential benefits I see coming from the changes that are the background of the quotation are contingently connected with the market. This is overdetermined by my calling such things unexpected and even ironic. When McMurtry accuses me of believing that freedom, or anything else, comes "necessarily" from any particular source, this is either a philosophically slovenly use of the idea of necessity, or a new and unfamiliar use of it. I did not say "ever more" freedom, nor any other excited exaggeration.

If McMurtry really wishes to impute to me a view about freedom, then it is also a strange thing that he does not tie it to his own original argument. In his paper, freedom in the market is mentioned, briefly, as being the ability to make transactions with no questions asked. It is then curious that he does not take the opportunity to support this against (what he thinks is) my view that market freedom is competitive alternatives.

Very peculiarly, he states instead:

As those who have read my article will know, I argue that the market model's universalization across the human condition, turning everything into an item for profitable sale from rainforests and ecosystems to students' future minds and lives, poses a problem to us because it reduces or eliminates our freedom. ${ }^{4}$

This is not true. I have shown my review copy of "Education and the Market Model" to another philosopher, who, like me, can find no trace of such an argument. Perhaps McMurtry has another paper called "Freedom and the Market Model," which he has in mind when responding to comments on the first one.

McMurtry's principal criticism of me is, then, in three ways displaced from the subject-matter: the quotation is not mentioned; my comments include no view about freedom; and his article has no continuous argument about freedom.

I turn now to a disagreement between us on formal logic. McMurtry states:

Barrett has committed the kind of compound fallacy now familiar in the ruling ideology of the "free market." Let $M$ stand for the Market and F for Freedom. The double fallacy is this: $M>F$, therefore $F>M$. The former is a fallacy because it assumes what is required to be proved. . The second argument is also a primary fallacy, known by logicians as. . . affirming the consequent. That is, it does not follow from $M>F$, even if it is true, that $\mathrm{F}$, any more than it follows from "Birds have two legs" that "All two-legged beings are birds." 5

According to the logic text that I learned from, affirming the consequent is a fallacy in propositional logic having the schema: $P>Q, Q$, therefore $P .^{6} M>$ $F$, therefore $F$ would not be a case of this, even if $M$ and $F$ were propositions. Since the fallacy takes its name from the second premise, not the conclusion, McMurtry just does not understand the fallacy he names. The example of the feathered bipeds is from predicate logic, not propositional, and does not instance 
the fallacy in question. In any case, if $M$ means the Market, $M>F$ is not a well-formed formula, but is a symbolisation that shows an unawareness of the different logical elements-propositions, terms, names, and so on.

Lastly, I would say that it is a gross non sequitur when McMurtry accuses someone not receptive to his so-called contradictions of "abandoning reason" by internalising market logic. This is because his argument comprises oppositions between two models (not within one model). People might miss the opposition because of something to do with education. For instance, the market's excellence-error-free work-could be thought to apply to a school routine comprising endless "exercises," marked down for errors, and not touching on any "deep and broad problems."

In fact, I think that some humanities departments closed down were very weak when measured against the criterion of posing "deep and broad problems." If so, McMurtry's two-model argument might describe a Chestertonian education $\rightarrow$ tactical naivete that actually makes it harder, not easier, to reason convincingly for the continuance of such departments.

These are just some of the reasons why I believe that McMurtry ought to be considerably more tempered and circumspect in the things he says against views or positions of others.

\section{Notes}

1John McMurtry, "Beyond Market Theology: Reply to Barrett and Woodhouse," Paideusis, 5(2), 1992, 34-37. This was in response to Richard Barrett, "Comments on 'Education and the Market Model'," Paideusis, 5(1), 1991, 45-49.

2John McMurtry, "Education and the Market Model," Paideusis, 5(1), 1991, 36-44.

3John McMurtry, "Beyond Market Theology," op. cit., 34.

4John McMurtry, ibid., 35.

${ }^{5}$ John McMurtry, ibid., 36.

${ }^{6}$ E.J.Lemmon, Beginning Logic (London: Nelson, 1965), 17. 